\title{
Influence of water/powder ratio in the mineral and synthetic casts
}

\author{
Rudys Rodolfo De Jesus Tavarez ${ }^{1}$, Rufino José Klug ${ }^{1}$, Mayana Soares Vieira' ${ }^{1}$, Gisele Lima Bezerra ${ }^{1}$, \\ Matheus Coelho Bandeca ${ }^{1}$, Leily Macedo Firoozmand ${ }^{2}$
}

\author{
${ }^{1}$ Universidade Ceuma - UNICEUMA, School of Dentistry, Department of Prosthodontics, São Luis, MA, Brazil \\ 2Universidade Federal do Maranhão UFMA, School of Dentistry, Department of Dental Materials, São Luis, MA, Brazil
}

Received for publication: July 17, 2014 Accepted: September 02, 2014

Correspondence to:

Rudys Rodolfo de Jesus Tavarez Universidade Ceuma - Pós-Graduação em Odontologia Rua Josué Montello, $\mathrm{n}^{0} 1$, Renascença II CEP 65.075-120 - São Luís - MA - Brasil Phone: +55 9832144127 E-mail: rudysd@uol.com.br

\begin{abstract}
Aim: To evaluate the influence of varying the water/powder ratio on the compressive strength of type IV mineral and synthetic casts. Methods: Four commercial brands of type IV mineral and synthetic casts were evaluated: Durone, Herostone, Fuji Rock, and Elite Rock. Ninety-six test samples were prepared from a silicone matrix, according to ADA's standard no. 25. The samples were prepared according to the manufacturer's recommendations with a normal water/powder ratio $(n=12)$ and with $20 \%$ extra water $(n=12)$, forming the control $(A)$ and experimental $(B)$ subgroups, respectively. Compressive strength tests were performed using a universal testing machine EMIC (DL 2000) with a load cell of 2,000 kgf/ $/ \mathrm{cm}^{2}$. The obtained data were analyzed statistically using two-way ANOVA and Tukey's test $(\alpha=5 \%)$. Results: The synthetic Elite Rock cast was statistically different from the one obtained when the portion of water indicated by the manufacturer was used; no significant differences were found in the remaining casts when the proportion of water was increased by $20 \%$. Conclusions: the groups of synthetic and mineral casts differed and the water increase (20\%) did not cause significant difference on the compressive strength of the materials.
\end{abstract}

Keywords: calcium sulfate; compressive strength; dental materials

\section{Introduction}

Models for fabricating dies and prosthetic pieces require the use of casts with high resistance, surface hardness and resistance to abrasion. Moreover, high accuracy is required to reproduce details and for dimensional stability ${ }^{1-3}$. Type IV and $\mathrm{V}$ casts are the materials of choice in these cases, as they have favorable mechanical properties such as high resistance, minimal setting expansion, and high surface hardness ${ }^{4-7}$.

Depending on the fabrication process, casts may be classified as mineral or synthetic. To obtain their inherent characteristics, mineral casts are fabricated by heating calcium sulfate dihydrate $\left(\mathrm{CaSO}_{4}-2 \mathrm{H}_{2} \mathrm{O}\right)$, which is converted into calcium sulfate hemihydrate $\left(\mathrm{CaSO}_{4} \cdot 1 / 2 \mathrm{H}_{2} \mathrm{O}\right)$. Depending on the calcination method, different forms of hemihydrate may be obtained, i.e., the $\beta$-hemihydrate form is known as a plaster cast, which consists of particles of large rhomboid crystals of irregular shape with capillary pores; while $\alpha$-hemihydrate, which contains smooth and dense particles, the powder being mainly indicated for die fabrication ${ }^{8}$. However, it is possible to produce $\alpha$ - and $\beta$-hemihydrate from the by-products of phosphoric acid production, resulting in the so-called synthetic casts. They are generally more expensive than mineral casts and their properties are identical or superior to those of conventional casts.

Using type IV mineral and synthetic casts, it is possible to fabricate models 
with smooth and hard surfaces, important characteristics that allow the waxing and sealing of edges with minimal abrasion during the production of fixed prostheses. These are some of the most frequently used casts, easy to produce and compatible with molding materials ${ }^{3-4}$. However, these casts expand in the first $24 \mathrm{~h}$ and shrink for up to two weeks after setting9.

Despite the high resistance and hardness of type IV casts, care must be taken during their fabrication. The water/powder ratio is considered a determining factor of the physical and chemical properties of a cast, and change in this ratio may alter these properties. An increase in the water/powder ratio increases the setting time and the possibility of producing a cast with fewer crystals per volume, lower resistance, and lower setting expansion ${ }^{8}$. On the other hand, less water will decrease the fluidity of the cast, preventing the exact replication of mold details ${ }^{10}$. This ratio varies among different commercial brands; between 0.22 and $0.24 \mathrm{~mL}$ of water per $100 \mathrm{~g}$ are required for type IV casts.

According to the American Dental Association (ADA) Specification no. 25, type IV casts, $1 \mathrm{~h}$ after mixing, must have a compressive strength of 5000 psi, equivalent to 351.53 $\mathrm{kgf} / \mathrm{cm}^{2}$ (ADA 25) ${ }^{11}$. The compressive strength of the casts is directly associated with their surface hardness and resistance to abrasion during handling in a clinic or laboratory, or during die casting, articulation, cutting, and duplication of the model ${ }^{12-13}$. The highest resistance to diametral traction of these casts occurs 120 min after setting ${ }^{14}$.

The null hypotheses tested in this study were: (1) there is no change in compressive strength between different brands of type IV mineral and synthetic casts; and (2) a $20 \%$ increase in the water/powder ratio does not affect the compressive strength of the tested casts.

\section{Materials and methods}

Ninety-six test samples were prepared, with dimensions of $20 \times 40 \mathrm{~mm}$, from four different commercial brands of mineral and synthetic type IV casts (Table 1). The samples were prepared using a standardized silicone matrix according to standard no. 25 of the ADA (Figure 1).

Test samples in each group of casts were prepared according to the manufacturers' instructions, with normal water/powder ratio $(\mathrm{n}=12)$ and an extra $20 \%$ of water

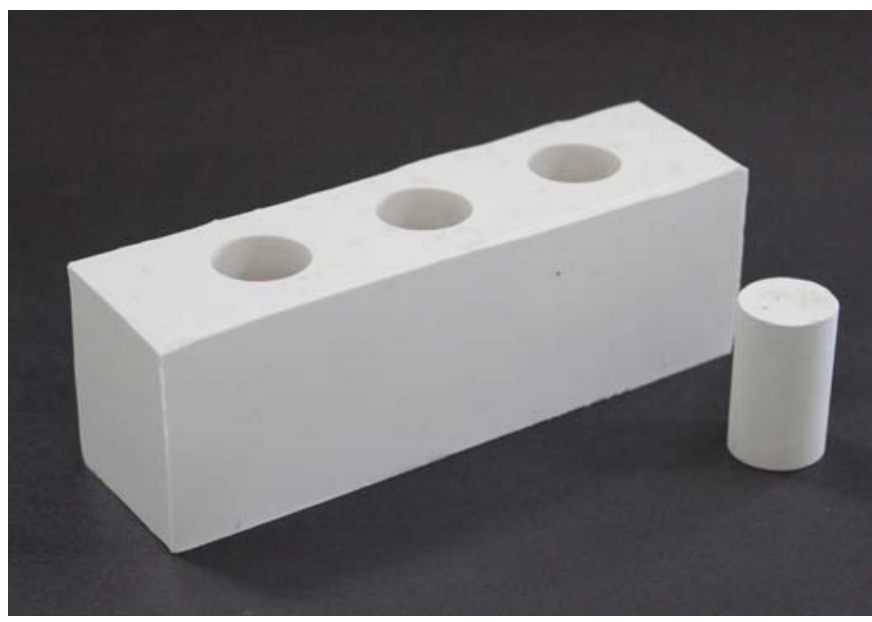

Fig. 1. Silicone mold and test sample.

$(\mathrm{n}=12)$, resulting in the control (A) and experimental (B) subgroups, respectively. The cast was prepared at a controlled temperature of $25 \pm 2{ }^{\circ} \mathrm{C}$ and a relative humidity of approximately $50 \pm 10 \%$ (Table 1). The casts were weighed on a precision scale (BIOPRECISA FA2104N, Curitiba, PR, Brazil) and mixed mechanically under vacuum (POLIDENTAL, São José dos Campos, SP, Brazil) for $30 \mathrm{~s}$.

After mixing, the casts were poured into silicon matrices with the help of a gypsum vibrator (VH Goldline, Araraquara, $\mathrm{SP}$, Brazil) for $1 \mathrm{~min}$. A sheet of glass was placed on the matrices, maintaining a constant weight of $1 \mathrm{~kg}$ as the casts set. After $1 \mathrm{~h}$, the test samples were removed and assessed for elements that may interfere with the compression test, such as bubbles, cracks and faults. The test samples with visible imperfections were discarded.

One hour after mixing, the test samples were subjected to compressive strength tests in a universal testing machine (EMIC DL2000, São José dos Pinhais, PR, Brazil) with a load cell of $2,000 \mathrm{kgf} / \mathrm{cm}^{2}$ and a displacement velocity of $0.5 \mathrm{~mm} / \mathrm{min}$.

Kolmogorov-Smirnov and Shapiro-Wilk (0.05\%) tests were used to confirm whether the analyzed data followed a normal distribution. As this was the case, the data were then analyzed statistically by two-way ANOVA and Tukey's tests $(\alpha 5 \%)$.

The same operator analyzed the fractures in the test samples, but he was blinded as regards the materials. The

Table 1. Specifications of the type IV casts used in the study.

\begin{tabular}{|c|c|c|c|c|c|c|}
\hline Group & & Description & Brand & $\begin{array}{c}\text { Batch } \\
\text { Expiration } \\
\text { date }\end{array}$ & $\operatorname{Normal}(A)$ & $\begin{array}{c}20 \% \\
\text { extra(B) }\end{array}$ \\
\hline \multirow[t]{2}{*}{ Mineral } & 1 & Durone IV cast & Dentsply Indústria e Comércio, Petrópolis, RJ, Brazil & $\begin{array}{c}\text { 649874E } \\
\text { Mar/15 }\end{array}$ & $19 \mathrm{~mL}$ & 22.8 \\
\hline & 2 & Herostone IV cast & Vigodent S/A Indústria e Comércio, Rio de Janeiro, RJ, Brazil & $\begin{array}{c}00712 \\
\text { Jul/2015 }\end{array}$ & $20 \mathrm{~mL}$ & $24 \mathrm{~mL}$ \\
\hline \multirow[t]{2}{*}{ Synthetic } & 3 & Elite Rock IV cast & ZhermackTechnical, BadiaPolesine (Rovigo), Italy & $\begin{array}{c}130508 \\
\text { Sep/2014 }\end{array}$ & $20 \mathrm{~mL}$ & $24 \mathrm{~mL}$ \\
\hline & 4 & Fuji Rock IV EP cast, Peal White & GC Europe N V, Leuven, Belgium & $\begin{array}{l}1201042 \\
\text { Jan/2015 }\end{array}$ & $20 \mathrm{~mL}$ & $24 \mathrm{~mL}$ \\
\hline
\end{tabular}


Table 2. Mean and standard deviation of compressive strength for each studied group.

\begin{tabular}{|c|c|c|c|c|}
\hline & \multirow[b]{2}{*}{ Groups } & \multicolumn{3}{|c|}{ Compressive strength (kgf) } \\
\hline & & $\begin{array}{c}\text { Indicated } \mathrm{H}_{2} \mathrm{O} \\
\text { proportion } \\
\text { (control) } \\
\text { A }\end{array}$ & $\begin{array}{c}\text { Increased } \mathrm{H}_{2} \mathrm{O} \\
\text { proportion } \\
\text { B }\end{array}$ & Total \\
\hline \multirow[t]{2}{*}{ Mineral } & G1: Durone & $1127.0(177.7)^{\star}$ & $1006.2(167.3)^{\star}$ & $1067.6(179.1)$ \\
\hline & G2: Herostone & $1102.3(315.1)^{*}$ & $955.9(107.9)^{*}$ & $1029.1(241.2)$ \\
\hline \multirow[t]{3}{*}{ Synthetic } & G3: Elite Rock & $1314.6(196.7)^{*}$ & $958.4(161.9)^{*}$ & $1136.5(253.2)$ \\
\hline & G4: Fuji Rock & $1119.7(65.6)^{*}$ & $952.5(93.6)^{*}$ & $1036.1(116.4)$ \\
\hline & Total & $1165.9(218.5)^{*}$ & $968.3(133.1)^{*}$ & $1067.1(205.4)$ \\
\hline
\end{tabular}

${ }^{*} n=12$

final assessment was made on the basis on the following scores: 1, medial longitudinal fracture; 2, lateral longitudinal fracture; and 3, composite fracture (both longitudinal and/or transversal associated with oblique fractures and multiple fragments).

\section{Results}

The mean and standard deviation of the studied groups and subgroups are shown in Table 2. Two-way ANOVA showed that both the cast type and the interaction effect did not significantly differ between the studied groups. However, when the effect of changing the water/powder ratio of the studied casts was analyzed, it was found to be statistically significant (Table 3).

The highest mean of compressive strength between the subgroups with the water/powder ratio recommended by the manufacturer was found for the Elite Rock synthetic cast G3 (Table 2, Figure 2).

With regard to the different fracture types in the test

Table 3. Two-way ANOVA for compressive strength data for different experimental groups.

\begin{tabular}{llllll}
\hline EFFECT & SQ & GL & QM & F & p \\
Cast & 144389.680 & 3 & 48129.893 & 1.549 & 0.209 \\
$\mathrm{H}_{2} \mathrm{O} \times$ powder ratio & 781255.109 & 1 & 781255.109 & 25.146 & $0.000^{*}$ \\
Interaction effect & 172884.954 & 3 & 57628.318 & 1.855 & 0.145 \\
Residual & 2236923.998 & 72 & 31068.389 & & \\
Total & $9.444 \mathrm{E} 7$ & 80 & & & \\
\hline
\end{tabular}

${ }^{*} p<0.05$

Table 4. Distribution of fracture types in studied samples.

\begin{tabular}{lllccc}
\hline \multicolumn{1}{c}{ GROUPS } & & \multicolumn{3}{c}{ Fracture (score) } \\
Mineral & G1: Durone & A & $2(20 \%)$ & $1(10 \%)$ & $7(70 \%)$ \\
& & B & $3(30 \%)$ & $3(30 \%)$ & $4(40 \%)$ \\
& G2: Herostone & A & $3(30 \%)$ & $1(10 \%)$ & $6(60 \%)$ \\
& & B & $4(40 \%)$ & $1(10 \%)$ & $5(50 \%)$ \\
Synthetic & G3: Elite Rock & A & $1(10 \%)$ & 0 & $9(90 \%)$ \\
& & B & $3(30 \%)$ & $3(30 \%)$ & $4(40 \%)$ \\
& G4: Fuji Rock & A & $3(0 \%)$ & $1(10 \%)$ & $6(60 \%)$ \\
& & B & $2(20 \%)$ & $2(20 \%)$ & $6(60 \%)$ \\
\hline
\end{tabular}

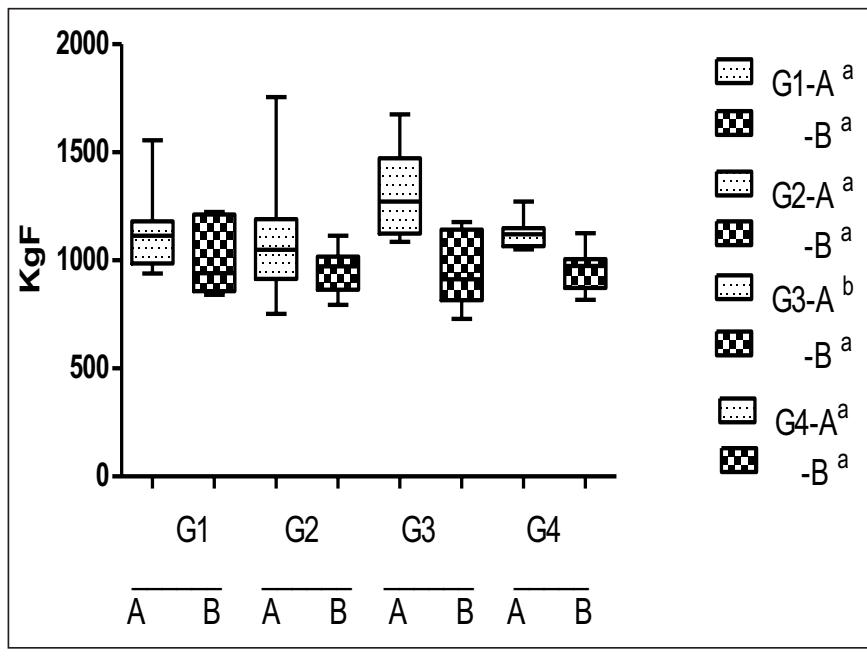

Fig. 2. Minimum and maximum values, mean and standard deviation (kgf) values for groups and Tukey's test $(\alpha=5 \%)$ results after compressive strength test.

samples, Table 4 shows that the predominant type was type 3 (multiple fractures) in all groups, mainly when the water/ powder ratio recommended by the manufacturer was used.

\section{Discussion}

Currently, mineral casts are commonly used for preparing study models, and it is noticed that the use of synthetic casts has become widely accepted in dentistry. Thus, when the compressive strength of type IV synthetic and mineral casts was analyzed, the first null hypothesis was not rejected but the second one was rejected, since the synthetic Elite Rock cast differed significantly from the other groups.

The compressive strength test is especially important, as it relates to the surface hardness of a model ${ }^{12}$. Cast resistance is directly affected by two factors, water/powder ratio and mixing time. In this study, the mixing time was standardized so that the results were not negatively influenced ${ }^{3,15}$.

The results obtained in this study showed that only the comparison of casts and the interaction effect did not significantly differ between the studied groups, confirming the results found in other studies ${ }^{1,16}$. However, when the water/ powder ratio was varied, significant differences were found 
among the test samples.

The compressive strength of casts appears to be materialdependent, as the post hoc statistical test demonstrates that only the Elite Rock synthetic cast had a higher mean resistance when the water/powder ratio indicated by the manufacturer was analyzed. The mineral casts and the other studied synthetic cast (Fuji Rock) differed from the Elite Rock cast but did not show significant differences from each other.

After the extra 20\% water was added, there was difference in compressive strength for the synthetic Elite Rock cast compared with the normal ratio. Moreover, the decrease in resistance to compression of this synthetic cast was found to be significant. When the amount of water was increased, small dihydrate crystals, which acted as anchor points for larger crystals, precipitated and the bonds between them were destroyed, increasing the porosity and hence lowering the resistance of the cast ${ }^{17-18}$. Therefore, an increase in the water/ powder ratio produces a more porous and less resistant cast, since the water evaporates and leaves empty spaces between the particles.

With regard to the types of fracture in the test samples, the obtained results showed that type 3 was the most frequent; few studies reported in the literature have assessed the type of fracture in test samples ${ }^{12}$. It is assumed that this predominance occurs because of the mechanical behavior of gypsum products during setting, since the greater the hardness of the material, the more friable it becomes. This explains the greater incidence of multiple fractures, especially when the normal water/powder ratio was maintained ${ }^{15,18-19}$.

According to the results of this study, it was concluded that there is no significant difference between compressive strength of synthetic and mineral casts and there is a significant decrease in compressive strength with additional $20 \%$ water in relation to powder, particularly in the synthetic Elite Rock cast. Further studies are required to prove the benefits and behavior of synthetic casts introduced in the market.

\section{References}

1. Duke P; Moore BK; Haug SP; Andres CJ. Study of the physical properties of type IV gypsum, resin-containing, and epoxy die materials. J Prosthet Dent. 2000; 83: 466-73.

2. Lindquist TJ; Stanford CM; Knox E. Influence of surface hardener on gypsum abrasion resistance and water sorption. J Prosthet Dent. 2003; 90: 441-6.

3. He LH; van Vuuren LJ; Planitz N, Swain MV. A micro-mechanical evaluation of the effects of die hardener on die stone. Dent Mater J. 2010; 29: 433-7.

4. Ragain JC; Grosko ML; Raj M; Ryan TN; Johnston WM. Detail reproduction, contact angles, and die hardness of elastomeric impression and gypsum die material combinations. Int J Prosthodont. 2000; 13: 214-20.

5. Sharma A, Shetty M, Hegde C, Shetty NS, Prasad DK. Comparative Evaluation of Dimensional Accuracy and Tensile Strength of a Type IV Gypsum Using Microwave and Air Drying Methods. J Indian Prosthodont Soc. 2013; 13: 525-30.

6. Gujjarlapudi MC, Reddy SV, Madineni PK, Ealla KK, Nunna VN, Manne $\mathrm{SD}$. Comparative evaluation of few physical properties of epoxy resin, resin-modified gypsum and conventional type IV gypsum die materials: an in vitro study. J Contemp Dent Pract. 2012; 13: 48-54.
7. Valente VS, Zanetti AL, Feltrin PP, Inoue RT, de Moura CD, Pádua LE. Dimensional accuracy of stone casts obtained with multiple pours into the same mold. ISRN Dent. 2012; 2012:730674. doi: 10.5402/2012/730674.

8. Anusavice KJ. Phillips' science of dental materials. 11th ed. Saint Louis: Elsevier; 2003.

9. Michalakis KX, Asar NV, Kapsampeli V, Magkavali-Trikka P, Pissiotis AL, Hirayama H. Delayed linear dimensional changes of five high strength gypsum products used for the fabrication of definitive casts. J Prosthet Dent. 2012; 108: 189-95.

10. Alsadi S, Combe E, Cheng YS. Properties of gypsum with the addition of gum Arabic and calcium hydroxide. J Prosthet Dent. 1996; 76: 530-4.

11. American National Standards/American Dental Association Specification No. 25. Dental gypsum products. New York: American National Standards Institute; 2000.

12. Schneider RL, Taylor TD. Compressive strength and surface hardness of type IV die stone when mixed with water substitutes. J Prosthet Dent. 1984; 52: 510-4.

13. Hiraguchi $H$, Nakagawa $H$, Wakashima M, Miyanaga $K$, Saigo

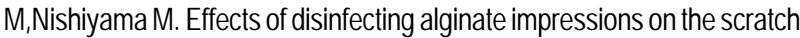
hardness of stone models. Dent Mater J. 2006. 25: 172-6.

14. Hersek N, Canay S, Akça K, Ciftçi Y. Tensile strength of type IV dental stones dried in a microwave oven. J Prosthet Dent. 2002; 87: 499-502.

15. Craig GC, Powers JM. Restorative dental materials. 10th ed. Missouri: Mosby Year Book; 1997. p. 63-73.

16. Silva MA, Vitti RP, Consani S, Sinhoreti MA, Mesquita MF, Consani $\mathrm{RL}$. Linear dimensional change, compressive strength and detail reproduction in type IV dental stone dried at room temperature and in a microwave oven. J Appl Oral Sci. 2012; 20: 588-93.

17. Khan Z, Morris JC, von Fraunhofer JA. Effect of irreversible hydrocolloid impressions on surface hardness of dental stone. J Prosthet Dent. 1984; 52: 435-7.

18. Van Noort R. Introduction to dental materials. 4. ed. London: Mosby; 2013.

19. Schwedhelm ER, Lepe X. Fracture strength of type IV and type $V$ die stone as a function of time. J Prosthet Dent. 1997; 78: 554-9. 